\title{
Universitetsuddannelsens relevans i samfundsvidenskabelige studerendes perspektiv
}

\author{
Laura Pérez Skardhamar, ph.d., pæedagogisk specialkonsulent og projektleder i \\ Pæedagogisk Center Samfundsvidenskab, Københavns Universitet
}

\author{
Charlotte Baarts, ph.d., lektor og studieleder ved Sociologisk Institut, Køben- \\ havns Universitet
}

\section{Videnskabelig artikel (anonym peer-review)}

\begin{abstract}
Det seneste årti har oplevet et stærkt fokus fra politikernes side på den praktiske relevans af universitetsuddannelser, og dette fokus har ofte været baseret på en snæver forståelse af 'praktisk relevans' som jobspecifikke kompetencer. Men et svar på spørgsmålet om, hvad der udgør jobspecifikke kompetencer, forudsætter en evne til at se ind i fremtiden og se, hvad det fremtidige arbejdsmarked vil kræve af studerende. Imidlertid tyder nyere uddannelsesforskning på, at de relevante, jobspecifikke kompetencer rettet mod behovene på arbejdsmarkedet bor fokusere på 'eksistentiel uddannelse' snarere end jobspecifikke og snævert skræddersyede færdigheder. På baggrund af kvalitative interviews med sociologiog antropologistuderende undersøger vi de studerendes opfattelser af forholdet mellem deres universitetsstudier og det fremtidige arbejdsmarked. Især ser vi på hvilke elementer af deres uddannelse, de studerende opfatter som relevante, herunder hvilken form for læring, de tror, vil være nyttig med hensyn til mulige jobfunktioner, de vil komme til at udfylde på et fremtidigt arbejdsmarked.
\end{abstract}

\section{Indledning}

Universitetsloven stiller krav til universitetsuddannelserne om at bedrive forskningsbaseret uddannelse, et krav som det, siden Karl Wilhelm Humboldt (1767-1835) udkastede sine visioner for videregående uddannelse, har været de danske universiteters kongstanke at realisere. Inden for uddannelsesforskning er der enighed om, at forskningsbaseret uddannelse er en central komponent i de studerendes læring (Robertson \& Blackler, 2006; Brew, 2010; Healey \& Jenkins, 2009; Levy et al., 2013), idet det anses for vitalt for alle studerende at udvikle evnen til at foretage vurderinger på basis af robust viden, undersøge problematikker, træffe rationelle beslutninger og forstå grundlaget for disse (Brew, 2010: 141). I forlængelse heraf har vi i det seneste årti været vidne til et stigende politisk fokus på, at ikke kun professionshøjskoler og professionsorienterede fag men også universitetsuddannelserne i højere og højere grad skal styre uddannelserne i retning af arbejdsmarkedsrelevans med særligt fokus på udvikling af kandidaternes arbejdsrelevante kompetencer (e.g. Udvalg for Kvalitet og Relevans i de Videregående Uddannelser, 2015). Desuden synes uddannelse at indgå som et centralt virkemiddel og parameter for konkurrencestatens succes (jf. Pedersen, 2014). I denne udvikling er spørgsmålet, om det ikke netop er gennem forskningsbaseret uddannelse, at universitetsuddannelserne opfylder regeringernes agenda for arbejdsmarkedsrelevant uddannelse; det vil sige, ved at udvikle de studerendes evne til at analysere og løse problemer som fagpersoner gennem involvering og aktiv deltagelse i forskning og forskningslignende aktiviteter? I den sammenhæng er det centrale spørgsmål, hvad de studerende selv oplever som relevansen af, at deres uddannelse er forskningsbaseret. 
På uddannelserne i Sociologi og Antropologi ved Københavns Universitet er størstedelen af undervisningen forskningsbaseret. Baseret på kvalitative interviews med sociologi- og antropologistuderende ved Københavns Universitet undersøger vi i denne artikel, hvad de studerende forstår ved relevans af deres uddannelse og desuden, hvordan de skaber sammenhæng mellem deres studier og forestillinger om det fremtidige arbejdsmarked.

\section{Teori}

Den britiske uddannelsesforsker Ronald Barnett rejser spørgsmålet om, hvad det vil sige at lære (2012), når læringen retter sig mod en fremtid, der - for studerende - er ukendt? Hvilken slags læring, spørger han, er den rette, når fremtiden netop ikke kendes (ibid)? Spørgsmålet er ikke bare generelt relevant i uddannelsesmæssig sammenhæng, men også specifikt med fokus på det politiske ønske om, at studerende skal udvikle arbejdsmarkedsrelevante kompetencer gennem deres universitetsstudier. Hvilke arbejdsmarkedsrelevante kompetencer skal studerende tilegne sig i forhold til det arbejdsmarked, de skal ud på efter fem års studier? Hvad ved vi egentlig om hvilke kompetencer, der til den tid vil blive efterspurgt? Og hvilke kompetencer kan siges at være arbejdsmarkedsrelevante? Det umiddelbare svar på disse spørgsmål synes at være 'generiske kompetencer', som kan anvendes i en mangfoldighed af situationer, selv i de situationer vi ikke på nuværende tidspunkt kan forudsige må opstå. Imidlertid er svaret ifølge Barnett ikke 'generiske kompetencer', men snarere at iværksætte en pædagogik for mennesket (Barnett, 2012:254). Herved foreslår han et skift for universitetslæring fra fokus på viden og kompetencer til en orientering mod de menneskelige kvaliteter og dispositioner som er en forudsætning for at skabe en positiv agenda i en grundlæggende usikker og superkompleks verden (Bamett, 2007:159). I nedenstående model ses Barnetts forslag til skitsering af pædagogiske muligheder for læring ved universitetet (figur 1):

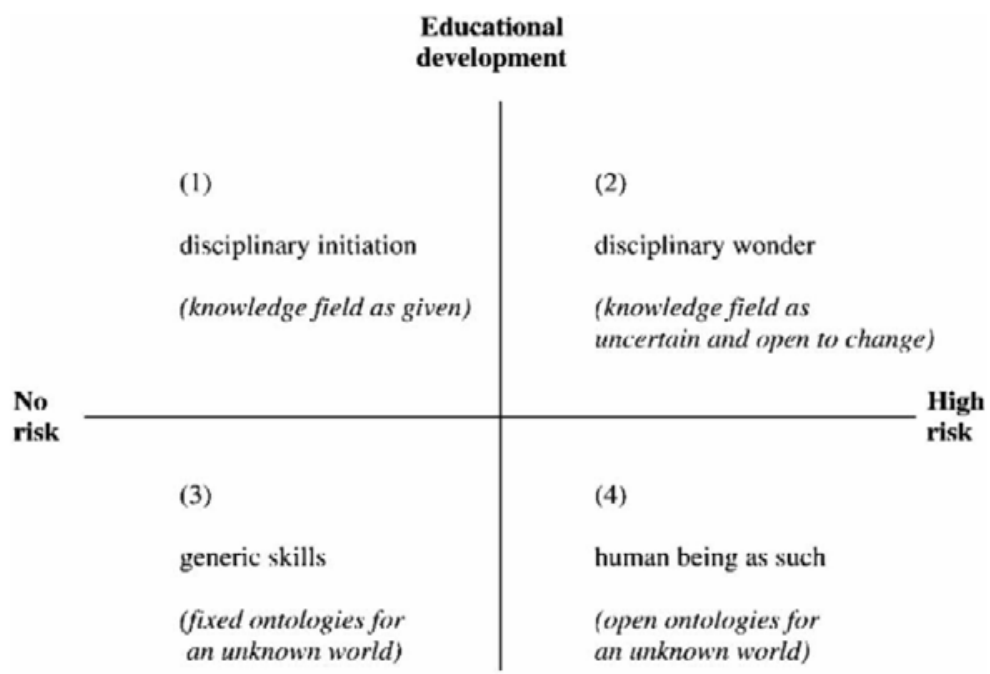

$$
\begin{gathered}
\text { Educational } \\
\text { transformation }
\end{gathered}
$$

Figure 1. Pedagogical options: a schema.

Figur 1: Læring på universitetet (Barnett, 2012: 72)

Modellen er bygget op af to akser, som tilsammen skaber fire felter for læringsmuligheder på universitetet. Modellens vertikale akse indikerer, hvorvidt fokus er på uddannelsesmæssig udvikling, der henviser til læring af forskellige kompetencer, eller uddannelsesmæssig transformation, som refererer til læring som menneskelig dannelse. Den horisontale akse viser graden af den studerendes oplevede risiko fra ingen risiko til høj risiko. 
Ud fra dette tegner de fire felter i modellen fire forskellige pædagogiske tilgange til læring ved universitetet, der har fokus på henholdsvis 1) 'faglig indvielse', 2) 'faglig undren', 3) 'almene færdigheder' og 4) 'eksistentiel dannelse'.

Med afsæt i disse fire beskrivelser af læringsmuligheder for studerende ved universitetet undersøger vi, hvorvidt og eventuelt hvordan disse opfattelser af læring forankrer sig blandt de studerende på uddannelserne i henholdsvis Sociologi og Antropologi. Vi retter særligt opmærksomheden imod, hvordan de studerende taler om relevans af deres studier i forhold til de opfattelser, de måtte have af den fremtid og det arbejdsmarked, som er dem både ukendt og usikkert. Ved at bruge Barnetts model som analytisk greb kan vi få blik for, hvordan de studerende etablerer forbindelser mellem på den ene side deres forestillinger om, hvad der for dem udgør relevante kompetencer i fremtiden, og på den anden side deres forståelser af, hvad de lærer og burde lære ved universitetet.

I feltet øverst til venstre bliver de studerendes læringsmuligheder konstitueret ved fokus på uddannelsesmæssig udvikling ved lav risiko. Dette indebærer, hvad Barnett kalder en 'faglig indvielse', hvor det vidensfelt, den studerende skal tilegne sig viden om, og som er nyt og ukendt for dem, er givet på forhånd. Læringsmålet er, at den studerende udvikler sin forståelse og sine kompetencer inden for den bestemte disciplin. Risikoen er lav, fordi det handler om, at den studerende tilegner sig den etablerede viden inden for faget.

I feltet øverst til højre er læringsmulighederne igen repræsenteret gennem uddannelsesmæssig udvikling, men ved høj risiko. Dette indebærer, at de studerende i højere grad bliver inviteret til at deltage aktivt i de undervisningsmæssige aktiviteter således, at de udvikler egne praksisser og tilgange til de læringsmæssige aspekter. Herved udgør læringsmålene i nogen grad et fokus på transformation af de studerendes kompetencer. Den læring, der her tilbydes, er udvikling af 'faglig undren', hvorved læringen synes at være en slags reproduktion af akademiske identiteter (ibid.:256). Dette er forbundet med en større risiko og usikkerhed, fordi der er mere fokus på den studerendes selvstændige deltagelse $\mathrm{i}$ at definere og producere ny faglig viden og mindre på tilegnelse af eksisterende viden inden for faget.

I feltet nederst til venstre bliver læringsmulighederne skabt gennem en tilgang, hvor transformation af de studerende er i fokus gennem lav risiko. Dette indebærer paradoksalt nok, at de studerende i nogen grad skal bringes ud af deres akademiske domæne med henblik på at danne sig således, at de kan begå sig i en tiltagende foranderlig verden. Undervisningen søger at danne de studerende ved tydeligt at definere, hvilke 'almene færdigheder' de skal udvikle.

Endelig tilbyder det sidste felt læring gennem uddannelsesmæssig transformation ved høj risiko. Læringsrummet skal kunne få de studerende til at danne sig gennem undervisningsformer, der hverken er etablerede eller sikre, men derimod udfordrende og eksperimenterende, og som ligeledes afslører, at viden, læring og dannelse er komplekse fænomener, der hele tiden udvider sig, snarere end bliver til begribelige fænomener. Gennem sådan 'eksistentiel dannelse' bliver læringsmulighederne til (ibid.:257).

\section{Metode}

Det empiriske materiale er tilvejebragt gennem 13 kvalitative interview med sociologi- og antropologistuderende ved Københavns Universitet i 2012. Interviewene varede ca. 1-2 timer. Der er en overvægt af sociologistuderende i materialet. De interviewede var på både kandidat- og bachelorniveau (5. eller 6 . semester), alle i 20'erne, og ligeligt fordelt mellem kønnene. Det empiriske materiale blev til i forbindelse med et kursusforløb ved Sociologisk Institut, hvor de tilmeldte studerende i samarbejde med kursets fagansvarlige (bl.a. denne artikels forfatter) skulle producere empiri med henblik på at undersøge studerendes forståelser og erfaringer med forskningsbaseret undervisning ved universitetet. 
I forbindelse med analysen af disse aspekter blev vi opmærksomme på, at det empiriske materiale rummer mange refleksioner om relevansen af de studerendes studier i forhold til anvendelsen af de lærte kompetencer på et fremtidigt arbejdsmarked, hvorfor vi har gjort dette til genstand for undersøgelse i nærværende artikel.

Idet vi således har genbesøgt det empiriske materiale med henblik på at identificere de studerendes forskellige forståelser af relevans i en kvalitativ tilgang inspireret af fænomenografisk metode (jf. Aswin, Abbas \& Mclean, 2014; Åkerlind, 2007). Med en empirisk sensitivitet over for interviewmaterialet samt empirisk kompleksitet har vi fokuseret vores blik på varianser i de studerendes relevansforståelser. Vi har i en iterativ metodisk proces kodet materialet på tværs af de interviewede studerende og har dermed ikke fokus på den enkelte studerendes meningsdannelse og livshistorie. Med denne metode har det været muligt at identificere tilstedeværelsen af multiple rationaler om værdien af det lærte og relevante kompetencer blandt de studerende.

Artiklen falder i tre dele. Efter denne indledning præsenteres analyseresultater i tre afsnit med tre forskellige relevansforståelser samt et afsnit med diskussion af disse fund. Artiklen afrundes med en konklusion, der opsummerer resultaterne.

\section{II . Variation i de studerendes forståelse af relevans i uddannelsen}

Samtalerne med de studerende reflekterer, at de skelner mellem uddannelsen på universitetet på den ene side og det, de kalder "virkeligheden derude", på den anden side. Denne adskillelse antyder, at de studerende opfatter læring under uddannelsen som adskilt fra anvendelse af deres læring i praksis. I nærværende artikel udfolder vi ikke dette skel yderligere, men noget tyder på, at de studerende kan opfatte universitetet og arbejdsmarkedet som to meget forskellige kontekster for anvendelse af deres læringsmæssige kompetencer således, at det lærte på universitetet ikke nødvendigvis slår til på arbejdsmarkedet eller korresponderer med arbejdsmarkedets praksis og behov.

\section{Relevans som teoretisk erkendelse der danner grundtilgangen til verden}

Spørgsmålet om, hvad de studerende kan bruge deres uddannelse til, når de er færdige, rejser de studerende bl.a. i forbindelse med deres overvejelser over, hvilken relevans det har, at de bliver undervist i teori:

\section{"[...] Og mange siger jo også, "hvad er det jeg skal bruge det her til, når jeg kommer ud i den virkelige verden, jeg skal jo ikke sidde og nørde teori". Men jeg mener stadig, at det ligger som en del af vores grundforståelse, at vi har væeret igennem det teori, vi har. Det kan godt væere, det ikke kommer direkte ud, når du sidder og skal lave en eller anden arbejdsopgave, men det ligger alligevel implicit i din tilgang til verden og en problematik og sådan noget."(Kandidatstuderende).}

Som den studerende udtrykker det, repræsenterer fagets teoretiske perspektiver en grundlæggende forandring i den studerendes færden i og møde med verden samt i måden, hvorpå den studerende beskæftiger sig med faglige spørgsmål. Derfor har teori relevans, selvom teori kan opleves, som den studerende antyder, som noget, der vanskeligt finder plads i en arbejdsmæssig sammenhæng ude i "den virkelige verden". Idet den studerende ikke alene anerkender, men også værdsætter, at der opdyrkes en implicit tilgang til verden i forbindelse med teoriundervisningen, formulerer den studerende en forståelse af læringens relevans, som placerer sig i Barnetts fjerde position (figur 1, felt 4). Læringsforståelsen repræsenterer ikke et fokus på udvikling af specifikke kompetencer eller avancement i den faglige viden, men netop på uddannelsesmæssig transformation sådan, at teoriundervisningen menes at styrke og skabe en kvalificeret forandring $\mathrm{i}$ selve den studerendes refleksive tilgang til egen og etableret viden om verden.

En anden studerende er også optaget af uddannelsens teori- og videnskabsteoriundervisnings relevans for arbejdsmarkedet: 
IP: "Ja helt sikkert. Jeg har en ide om, at vi har meget videnskabsteori i forhold til andre, og det, synes jeg, er en styrke på mange måder. Måske ikke på arbejdsmarkedet, men i hvert fald, når man studerer, synes jeg."

I:" Er det noget som du interesserer dig for - videnskabsteori?"

IP: "Ja, enormt meget, men jeg har også lidt en anelse om, at det er rigtig godt nu, mens man studerer, men jeg ved ikke, hvor meget man kan bruge det, hvis man skal have et rigtigt arbejde. Men jeg synes, at den der måde at kunne vurdere kvaliteten af den viden, man opnär og hvordan osv., er ret interessant. [....]. Altså, jeg tror, det er det, der er styrken ved det videnskabsteori, vi lærer. Og det hænger også lidt sammen med det, jeg sagde om sammenhæenge, at man har sådan en bagvedliggende teori, som gor en i stand til at se nogle storre sammenhæenge."(Bachelorstuderende).

Skønt den studerende ikke umiddelbart vurderer, at hun i læringen af videnskabsteori udvikler relevante arbejdsmarkedskompetencer, identificerer hun en anden slags relevans ved faget, der peger på, at videnskabsteoretisk viden gør den studerende i stand til at vurdere kvaliteten af anden viden, se sammenhænge og identificere bagvedliggende strukturerer for disse sammenhænge. Denne relevansforståelse refererer også til Barnett-modellens fjerde position (felt 4), hvor læringsmålene er, at studerende kan navigere i det, Barnett kalder åbne ontologier og i en kontinuerlig foranderlig væren som sådan (Bamett, 2012: 72). Skønt begge studerende ovenfor formulerer en forestillet afstand fra det, de lærer på universitetet, til det, der skal bruges på arbejdsmarkedet, italesætter ingen af dem dette som et problem. Tværtimod formulerer de deres identifikation af afstand mellem læring af teori og arbejdsmarkedsrelevante kompetencer til en for dem meningsfuld forståelse af, at faglig (teoretisk) viden udgør en selvstændig og væsentlig del af deres dannelse. Hermed bliver deres tolkning af relevansen af det lærte på uddannelsen sat i relation til deres forestillinger om, hvad de forventer, at det lærte kan bruges til i et "rigtig arbejde". I denne relevansforståelse bliver det at være universitetsstuderende, få teoretiske og metodologiske erkendelser samt at komme tæet på forskning tilskrevet mening og værdi i sig selv. Det drejer sig om en art eksistentiel dannelse, hvor undervisning og læring understøtter den studerende i at forandre sig og opdyrke en grundlæggende refleksiv tilgang til verden.

\section{Relevans som det at bruge faget til at gøre en forskel}

Foruden opdyrkelsen af en åben og refleksiv grundtilgang til (viden om) verden omtaler de studerende også relevans af deres uddannelser i forhold til at kunne gøre en forskel og ændre noget i samfundet eksempelvis i forhold til udsatte grupper:

"Det er jo fx når man undersøger eller beskæftiger sig med nogle emner hvor at - ja det handler måske om nogle udsatte grupper eller nogle menneskers liv som man - ikke sådan det enkelte individ eller de personlige historier, men mere sådan - når man laver en undersøgelse af nogles identitet. Et projekt jeg har lavet med [xx-]identitet, hvor man undersøger noget, som vedrører nogle mennesker, og som handler om deres liv, og hvor man kan bruge det, også i nogle storre samfundsperspektiver. Det bliver sådan utrolig omt, men det der med faktisk at kunne bruge viden til at gøre, måske gøre nogle menneskers liv bedre eller pàpege nogle problematikker i samfundet. Det er det, jeg gerne vil, og det er der, hvor jeg synes, det bliver rigtig fedt."(Bachelorstuderende).

Den studerende finder uddannelsen særlig relevant i de sammenhænge, hvor fagene involverer aktuelle samfundsmæssige emner, eller hvor hun i projektarbejde kommer i kontakt med menneskers levede liv. I disse sammenhænge bliver det særligt tydeligt for den studerende, at læringen under uddannelsen kan anvendes i praksis til forhåbentlig at 
gøre en mærkbar og positiv forskel for de involverede personer eller grupper. Det væsentlige i denne relevansforståelse er, at faget anvendes til at analysere nogle konkrete problemstillinger i samfundet, og at dette ændrer noget for nogle konkrete mennesker.

I Barnetts model placerer den studerendes relevansforståelse sig på den vertikale akse for uddannelsesmæssig udvikling i anden position (figur 1, felt 2), som omhandler "faglig undren" snarere end den horisontale akse for uddannelsesmæssig transformation. Fagets viden og begreber skal bruges til at gøre en forskel for andre mere eller mindre konkrete målgrupper i samfundet snarere end til den studerendes egen dannelse som en værdi i sig selv. Den skabte faglige viden bliver et udgangspunkt for handling. Således er den studerendes læring og vidensproduktion forbundet med en vis grad af risiko i den forstand, at den studerende selvstændigt definerer problemer og hermed producerer (potentielt) ny viden inden for faget. I dette ønskes den faglige viden omsat til at kunne gøre en forskel i verden uden for den faglige forskningsdisciplins grænser.

Pointen om at gå til grænserne for den eksisterende faglige viden i faget er også tydelig i det næste citat, hvor den studerende ikke kun er optaget af at skabe håndgribelig forandring i samfundet for konkrete mennesker men også er optaget af at gå til grænsen for den eksisterende viden:

\section{l: "Hvorfor er det spændende at se tingene på andre måder? Hvorfor er det en god ting?" \\ IP: "Hvorfor? Ja det er svært at sige hvorfor, jeg tror bare, at det virker inspire- rende, eller at det, ja det tror jeg, jeg tror ikke rigtig, jeg kan komme det nær- mere. Jeg tror også, jeg synes, at det er vigtigt, at man har sådan en fantasi, så- dan én, at man kan forestille sig, at tingene kunne være anderledes, end de er." I: "Okay, hvorfor?" \\ IP: "Jamen, fordi ellers så kan der jo ikke ske nogen forandring, hvis man bare tror, at verden er, som den er, og sådan er det, men jeg synes, det er vigtigt, at mennesker generelt kan forestille sig, at tingene kunne blive set på en anden måde, eller at samfundet kunne bygges op på en anden måde eller sådan. "(Ba- chelorstuderende).}

Den studerende refererer til nogle grundlæggende faglige kvalifikationer og færdigheder i relation til samfundsopbygning inden for såvel sociologien som antropologien, der vedrører kritisk refleksion og det at stille spørgsmålstegn ved fagets eksisterende selvfølgeligheder ved brug af det, den studerende omtaler som (faglig) "fantasi". Læring af en sådan faglig fantasi har for den studerende praksisrelevans i forhold til generelt at kunne skabe forandringer og udvikle samfund. Denne forståelse placerer sig som nævnt i Barnetts anden position (figur 1, felt 2) med vægt på uddannelsesmæssig udvikling og samtidig med vægt på, at udvikling kræver, at der tages en stor risiko ved at stille sig undrende og kritisk refleksiv over for fagets eksisterende forståelser og begreber. Mens de samfundsvidenskabelige studerendes første relevansforståelse kan siges at have stor vægt på eksistentiel dannelse i sig selv og mindre vægt på praksisrelevans, er relevansforståelsen her netop fokuseret på, hvad der kan blive relevant i praksis.

\section{Relevans som tilegnelse af redskaber og generalistkompetencer}

I de første to analytiske temaer vedrørende henholdsvis teori og at gøre en forskel indstiftede de studerende et skel mellem læring under uddannelse og anvendelse af denne i "virkeligheden derude" på arbejdsmarkedet. I det følgende analyseafsnit bliver adskillelsen mellem universitetet og "virkeligheden derude" mindre væesentlig, når de studerende taler om relevans som tilegnelse af redskaber og specifikke kompetencer. Et bud på opløsningen af dette skel kan være, at læring af specifikke kompetencer i de studerendes øjne har direkte overførbarhed mellem universitetet og arbejdsmarkedet, hvorved skellet opløses. 
IP: "[...]J eg kan bare rigtig godt lide at vide sådan "okay jamen, det er her jeg sidder og lærer nu, hvad vil jeg sådan faktisk kunne bruge det til?". Jeg klikker fra, hvis ikke jeg ved, hvad jeg kan bruge det til, hvis jeg synes, at en teori ikke er anvendelsesdygtig eller en metode, jeg lærer, ikke er sådan konkret nok til, at jeg kan sige, okay når jeg så skal søge et studiejob, så kan jeg sige til min arbejdsgiver: jeg har lært det her, og det kan du bruge, derfor kan du bruge mig til det og det", eller sådan. Det har jeg brug for på det her studie, som nogen gange godt kan blive sådan lidt oppe i skyerne. "(Bachelorstuderende).

Uddannelsens relevans knytter sig for den studerende direkte til, hvad hun konkret kan formidle til en potentiel arbejdsgiver om, hvad hun kan, og dermed hvad hun kan bruges til. Den studerende etablerer meget målrettet en lineær forbindelse mellem læring af teori og metode og konkret anvendelse af disse i praksis. I de tilfælde, hvor en sådan forbindelse ikke kan skabes, bliver uddannelsesindholdet for denne studerende irrelevant. En tilsvarende relevansforståelse er på spil for den studerende i nedenstående citat: IP: "[...] Og så har jeg jo en forestilling om, at det er det, jeg skal arbejde med, at det er den måde, jeg skal arbejde pà. Jeg har ikke en forestilling om, at jeg skal forske, men jeg har en forestilling om, at jeg skal arbejde i en virksomhed som skal lave denne her form for analyser. Og det har jeg jo lært i den opgave, jeg har i hvert fald fået et lille indblik i hvordan man kunne gøre det."(Bachelorstuderende).

I ovenstående knytter den studerende direkte forbindelser mellem brugen af en bestemt slags analyser, som hun vurderer er anvendelige i såvel den skriftlige universitetsopgave som i en forestillet opgave stillet af en bestemt analysevirksomhed. På uddannelsen kan hun øve sig i at gennemføre disse analyser og på den baggrund bruge dem på kompetent vis, sà snart hun sidder i en stilling, hvor hun skal udarbejde dem i en virksomhed. Den studerendes relevansforståelse er således stærkt optaget af, at der skal være direkte overensstemmelse mellem det, der læres på uddannelsen, og det, der kan bruges i arbejdslivet.

\section{De tre relevansforståelser og betydning for universitetspæedagogikken}

I Barnetts model placerer dette sig i tredje position (figur 1, felt 3), hvor læringen orienterer sig mod læring af almene færdigheder, der med relativ stor sikkerhed vil finde anvendelse i en endnu ukendt fremtid. Det er for eksempel specifikke metoder og analysetilgange samt almen analytisk kompetence, som tegner de studerendes opfattelse af, hvad der er relevant læring her, og der tages ingen risiko. På den vertikale akse placerer de studerendes relevansforståelse sig i positionen: uddannelsesmæssig transformation, fordi fokus ikke er på traditionel fagindviende universitetsuddannelse, hvor det handler om at avancere i den faglige forståelse som i Barnetts første position (figur 1, felt 1) og heller ikke om at udvide den faglige forståelse ved at gå til grænsen af det kendte som i den anden position (figur 1, felt 2). Relevansforståelsen handler her om at klæde den studerende på til at navigere på et fremtidigt og derfor ukendt arbejdsmarked ved at optræne akademiske generalistkvalifikationer og -færdigheder.

Mens den første relevansforståelse, som de studerende forankrede i læring af teori, kan beskrives som eksistentiel funderet og som tæt forbundet med Barnetts vision om en pædagogik for mennesket med primært fokus på de menneskelige kvaliteter og dispositioner, italesætter de studerende gennem den anden relevansforståelse et ideal for praksisrelevant læring, der udfordrer grænserne for den faglige disciplin gennem ønsket om at bruge sin faglighed til at gøre en samfundsmæssig forskel for særligt udsatte grupper af mennesker. Sidst, men ikke mindst, har de studerendes italesættelse af denne tredje relevansforståelse fokus på praktisk relevante færdigheder og kompetencer, der kan bruges en til en på arbejdsmarkedet. 
Til den politiske agendas fokus på uddannelsens arbejdsmarkedsrelevans tilføjer denne analyse således en kvalitativ indsigt i de studerendes egne forståelser af den forskningsbaserede uddannelses relevans. Analysen viser, at relevansen ikke er isoleret til erhvervsrettede generalistkompetencer men også indbefatter en oplevelse af at blive eksistentielt dannet som menneske og fagperson. Dette er ifølge Barnett netop det, der skal til, for at den studerende er klædt på til en ukendt fremtids problemer og udfordringer. Til udvikling af den forskningsbaserede uddannelse inden for universitetspædagogikken åbner dette op for mange udfordringer og muligheder, herunder ikke mindst spørgsmålet om og svaret på, hvordan undervisning og læring med høj risiko kan styrkes og få mere plads til udfoldelse inden for den eksisterende uddannelsesstruktur.

\section{I I. Konklusion}

De samfundsvidenskabelige studerende italesætter tre kvalitativt forskellige opfattelser af relevans af det, de lærer på uddannelsen. For det første beretter de studerende om værdien af eksistentiel dannelse som en udviklende del af teori under uddannelsen på universitetet. For det andet beretter de studerende om værdien af fagets viden og de faglige kvalifikationer og færdigheder, som gør den studerende i stand til at tænke nyt om og løse konkrete problemstillinger og dermed forhåbentligt gøre den studerende i stand til i et arbejdsliv at gøre en positiv forskel for konkrete grupper af mennesker i samfundet. For det tredje beretter de studerende om nødvendigheden af, at de tilegner sig generelle akademiske færdigheder og kompetencer, som de kan bruge direkte på arbejdsmarkedet. Ved brug af Barnetts teoretiske model som analyseramme får vi et unikt indblik i, hvordan en flerhed af diskursive rationaler er på spil i specifikke sociologiog antropologistuderendes forholden sig til relevansen af deres uddannelse.

Artiklen peger på, at de studerende er bemærkelsesværdigt nuancerede og dynamiske i deres forståelser af uddannelsens relevans i et spænd fra erhvervsrettede generalistkompetencer til teoretisk dannelse. Med afsæt i Barnetts vision kan ovenstående indsigt i de studerendes egne nuancerede forståelser tolkes som et konkret eksempel på, at de nødvendige menneskelige kvaliteter og dispositioner som et superkomplekst samfund behøver, kommer til udtryk blandt disse specifikke samfundsvidenskabelige studerende i denne specifikke kontekst.

Laura Pérez Skardhamar har siden marts 2013 væeret pæedagogisk specialkonsulent og projektleder i Pæedagogisk Center Samfundsvidenskab, Københavns Universitet. Hun arbejder med uddannelsesudvikling og samarbejde på tværs af universitetets fakulteter i projekter om forskningsbaseret uddannelse og internationalisering samt adjunktsupervision mv. Lauras forskningsinteresser centrerer sig om kulturanalytiske tilgange til undervisning, læering og praksisrelationer på videregående uddannelser.

Charlotte Baarts er lektor og studieleder ved Sociologisk Institut, Københavns Universitet, Hendes forskningsinteresser centrerer sig om undersøgelse af forskellige vidensformer, $f_{x}$ kropslig og sproglig viden, og hvordan disse praktiseres. Dette forhold mellem viden og kunnen har hun beskæftiget sig med inden for områder som arbejdsmiljø og sikkerhed, alternative behandlingsformer samt forskningsbaseret uddannelse. Sidstnæevnte er et igangværende forskningsprojekt blandt såvel forskere som studerende ved universitetet.

\section{Litteratur}

Aswin, P., Abbas, A. \& Mclean, M. (2014). How do students' accounts of sociology change over the course of their graduate degrees? Higher Education, 672), 219234.

Barnett, R. (2012). Learning for an unknown future. Higher Education Research and Development, 23(3), 247-260.

Barnett, R. (2007). The Will to Learn: Being a Student in an Age of Uncertainty. New York: Society of Research into Higher Education \& Open University Press. 
Brew, A. (2010). Imperatives and challenges in integrating teaching and research. Higher Education Research and Development, 29 (2) 139-150.

Healey, M. \& J enkins, A. (2009). Developing students as researchers. Proceedings of the Newport NEXUS conference. Centre for Excellence in Learning and Teaching, special publication, No. 1, 7-11.

Levy, B. L. M.; Thomas, E. E., Drago, K. \& Rex, L. A. (2013). Examining studies of inquiry-based learning in three fields of education: Sparking generative conversation. Journal of Teacher Education, 64(5), 387-408.

Pedersen, K. O. (2014). Konkurrencestaten. København: Hans Reitzels Forlag.

Robertson, J. \& Blackler, G. (2006). Students' experiences of learning in a research environment. Higher Education Research and Development, 25(3), 215-229.

Udvalg for Kvalitet og Relevans i de Videregående Uddannelser (2015). Nye veje og høje mål. Kvalitetsudvalgets forslag til reform af de videregående uddannelser. Downloaded den 15/8-2015: http://ufm.dk/publikationer/2015/nye-veje-og-hojemal.

Åkerlind, G. S. (2007). Variation and commonality in phenomenographic research methods. Higher Education research \& Development, 24(4), 321-334. 